\title{
Komparasi Tingkat Aksesibilitas Jaringan Transportasi Publik bagi Pekerja Ulang-Alik di Kawasan Surabaya Metropolitan Area
}

\author{
Comparison of Public Transportation Network Accessibility for \\ Commuter Workers in Surabaya Metropolitan Area
}

Salsa Shabrina ${ }^{1}$, Siti Nurlaela ${ }^{1}$

Diterima: 12 Agustus 2020

Disetujui: 18 September 2020

\begin{abstract}
Abstrak: Pergerakan pekerja ulang-alik di kawasan Surabaya Metropolitan Area didominasi oleh pengguna moda transportasi pribadi. Kurangnya pengguna moda transportasi publik disebabkan oleh permasalahan aksesibilitas seperti waktu tempuh yang lama $(33,9 \%)$ dan kurang praktis $(32,7 \%)$. Penelitian-penelitian sebelumnya telah berupaya untuk mendorong peralihan moda melalui eksplorasi faktor yang dapat diintervensi dari sudut pandang pekerja sebagai pelaku perjalanan. Namun, penelitian-penelitian tersebut belum mengidentifikasi penyebab kurangnya daya saing transportasi publik, khususnya dari segi tingkat aksesibilitas serta faktor-faktor yang mempengaruhinya. Oleh karena itu, penelitian ini dilakukan untuk mengetahui faktor-faktor yang mempengaruhi tingkat aksesibilitas jaringan transportasi publik bagi pekerja ulang-alik di Surabaya Metropolitan Area berdasarkan komparasi tingkat aksesibilitas di Sidoarjo-Surabaya dan Gresik-Surabaya dengan menggunakan metode SNAMUTS. Hasil studi menunjukkan bahwa tingkat aksesibilitas di Surabaya Metropolitan Area dipengaruhi oleh hambatan perjalanan, trayek angkutan umum, waktu perjalanan, dan frekuensi angkutan umum. Aksesibilitas di SidoarjoSurabaya dapat ditingkatkan melalui penambahan 1 trayek angkutan umum pada Kecamatan Gedangan serta peningkatan frekuensi angkutan umum menjadi 4 unit per jam pada Kecamatan Waru dan Sedati. Sedangkan pada Gresik-Surabaya, aksesibilitas dapat ditingkatkan melalui penambahan 1 trayek angkutan umum di Kecamatan Menganti dan peningkatan frekuensi angkutan umum menjadi 4 unit per jam pada Kecamatan Cerme.
\end{abstract}

Keyword: aksesibilitas berbasis jaringan, faktor pengaruh, Surabaya metropolitan area, transportasi publik

\begin{abstract}
Movement of commuter workers in Surabaya Metropolitan Area is dominated by private transportation modes users. Lack of public transportation users is caused by accessibility problems such as long travel time (33.9\%) and less practicality (32.7\%). Previous studies have attempted to encourage modal shifting through exploration of factors that can be intervened from perspective of workers as travelers. However, these studies have not identified causes for lack of public transportation competitiveness, particularly in terms of accessibility level and factors that influence it. Therefore, this study aims to determine factors that affect public transportation networks accessibility for commuter workers in Surabaya Metropolitan Area based on comparison of accessibility level in Sidoarjo-Surabaya and Gresik-Surabaya using SNAMUTS method. Results of this study show that accessibility level in Surabaya Metropolitan Area is influenced by travel impedances, public transport routes, travel times, and public transportation frequency. Accessibility in Sidoarjo-Surabaya can be improved by adding 1 public transport route in Gedangan District and increasing public transportation frequency to 4 units per hour in Waru and Sedati Districts. Whereas in Gresik-Surabaya, accessibility can be improved through
\end{abstract}

\footnotetext{
${ }^{1}$ Departemen Perencanaan Wilayah dan Kota, Institut Teknologi Sepuluh Nopember
} 
addition of 1 public transport route in Menganti District and increasing public transportation frequency to 4 units per hour in Cerme District.

Keywords: network based accessibility, influence factor, Surabaya Metropolitan Area, public transportation

\section{PENDAHULUAN}

Kota Surabaya sebagai pusat dari kawasan Gerbangkertasusila mengalami perkembangan yang lebih pesat daripada kota-kota lain di Jawa Timur (Jawa Timur, 2012). Namun, pertumbuhan Kota Surabaya terbatasi oleh ketersediaan lahan serta peningkatan harga lahan. Hal ini mengakibatkan terjadinya fenomena urban sprawl atau ekspansi yang mengarah ke luar kota dalam jarak yang tidak terlalu jauh. Fenomena pertumbuhan kota yang berada dalam radius $20 \mathrm{~km}$ dari pusat Kota Surabaya membentuk kawasan Surabaya Metropolitan Area (SMA) yang meliputi Kabupaten Sidoarjo, Kabupaten Gresik, dan Kabupaten Bangkalan (Yagi, Aida, Nagayama, \& Kudo, 2009). Fenomena urban sprawl tersebut mendorong terjadinya peningkatan mobilitas penduduk dari kawasan pinggiran menuju pusat kota (Umilia, 2013).

Pada umumnya, mobilitas yang terbentuk berupa pergerakan komuter atau ulangalik yang merupakan pergerakan di luar kabupaten/kota tempat tinggal yang dilakukan secara rutin untuk pergi dan pulang pada hari yang sama. Pada tahun 2017, terdapat 305,232 orang yang melakukan pergerakan ulang-alik di kawasan Surabaya Metropolitan Area. Pergerakan tersebut didominasi oleh perjalanan menuju Kota Surabaya, yang mencapai $56.7 \%$ dari total perjalanan, dengan tujuan kegiatan utama untuk bekerja dengan persentase sebesar 79,2\% (Statistik, 2017).

Pola pergerakan ulang-alik di kawasan Surabaya Metropolitan Area didominasi oleh penggunaan kendaraan pribadi berupa motor $(84,4 \%)$ dan mobil $(9,1 \%)$ (Statistik, 2017). Pergerakan ulang-alik dengan kendaraan pribadi mengakibatkan penurunan tingkat pelayanan pada Jalan Ahmad Yani sebagai jalur penghubung utama antara Surabaya dan Sidoarjo serta kemacetan pada area perbatasan selatan dan barat daya Kota Surabaya (Natasha \& Handayeni, 2019). Tingkat kemacetan yang tinggi tersebut secara tidak langsung dapat mengakibatkan tingginya biaya perjalanan serta tingkat produktivitas pekerja yang rendah (Setyodhono, 2017). Bila tidak ditangani, kemacetan yang mengganggu mobilitas pekerja dapat memengaruhi produktivitas Kota Surabaya (Yagi et al., 2009).

Meskipun menimbulkan dampak negatif, pekerja ulang-alik tetap menggunakan kendaraan pribadi karena adanya permasalahan aksesibilitas seperti waktu tempuh yang lama saat menggunakan kendaraan umum, ketidakpraktisan penggunaan kendaraan umum, serta jauhnya akses menuju kendaraan umum (Statistik, 2017). Secara umum, pengambilan keputusan terkait penggunaan jenis moda transportasi tertentu oleh pekerja ulang-alik dipengaruhi oleh berbagai faktor, seperti konektivitas, aksesibilitas, dan kualitas pelayanan (Winarno \& Risdianto, 2018). Variabel lain yang memengaruhi pemilihan moda transportasi meliputi faktor usia, jenis kelamin, tingkat pendidikan, status pekerjaan, rata-rata penghasilan, jarak rumah ke tempat kerja, lama waktu tempuh, dan biaya transportasi (Setyodhono, 2017).

Untuk mengatasi permasalahan tersebut, penelitian sebelumnya merekomendasikan pelaksanaan intervensi preferensi pekerja ulang-alik agar memilih moda transportasi publik melalui perbaikan kemudahan untuk mencapai tujuan serta pengurangan biaya perjalanan dan waktu tempuh dengan kendaraan umum (Natasha \& Handayeni, 2019). Penelitian lainnya merekomendasikan intervensi pada karakteristik pola perjalanan dan karakteristik fasilitas moda dengan variabel paling berpengaruh 
berupa waktu dan biaya perjalanan (Louisa, 2016). Namun, belum terdapat penelitian yang menilai tingkat aksesibilitas jaringan transportasi publik yang menjadi penyebab pekerja ulang - alik enggan melakukan pengalihan moda dari kendaraan pribadi menjadi transportasi publik. Oleh karena itu, diperlukan pengukuran tingkat aksesibilitas dari jaringan transportasi publik.

Aksesibilitas merupakan tingkat kemudahan untuk mencapai suatu tempat (Grengs, 2010) atau untuk memeroleh kesempatan pelayanan (Jiang, 2017). Aksesibilitas juga menggambarkan kemampuan individu untuk mencapai layanan dan aktivitas yang diinginkan berkaitan dengan waktu dan biaya yang harus disediakan (Litman, 2017). Aksesibilitas dapat diukur menggunakan beragam metode seperti pengukuran normatif, pengukuran positif (Páez, Scott, \& Morency, 2012), spatial separation measures, contour measures, gravity measures, competition measaures, time-space measures, utility measures, dan network measures (Curtis \& Scheurer, 2010)

Pada penelitian ini, dilakukan pengukuran tingkat aksesibilitas berbasis jaringan serta identifikasi faktor-faktor yang mempengaruhi aksesibilitas menggunakan metode Spatial Network Analysis for Multimodal Urban Transport System (SNAMUTS) yang dikembangkan oleh Scheurer dan Curtis dalam (Curtis \& Scheurer, 2010). SNAMUTS merupakan metode yang digunakan untuk menilai tingkat aksesibilitas berbasis jaringan transportasi, misalnya eksplorasi membandingkan kinerja aksesibilitas sistem jaringan transportasi publik dibandingkan dengan sistem jaringan transportasi kendaraan pribadi, baik saat macet ataupun arus bebas (Curtis \& Scheurer, 2010). Kelebihan dari SNAMUTS adalah kemampuan mengidentifikasi dan memvisualkan berbagai metode pengukuran aksesibilitas dalam hal tingkat cakupan geografis, tingkat konektivitas jaringan, tingkat kompetitif jaringan dalam hal kecepatan moda pergerakan, dan tingkat aksesibilitas keseluruhan dengan mengkombinasikan berbagai metode pengukuran dalam bentuk nilai composite accessibility. Hasil pengukuran tersebut dapat menjadi pertimbangan untuk pilihan kebijakan transportasi berkelanjutan, misalnya dalam kebijakan pusat-pusat aktivitas mana yang perlu dipromosikan perkembangannya, dan rute transportasi publik mana yang perlu diprioritaskan untuk dikembangkan.

Dalam penelitian ini, penggunaan metode SNAMUTS melalui pengukuran tingkat keterpusatan suatu terminal atau titik transit/titik transfer pada jaringan transportasi publik dengan cara:

1. Seberapa mudah titk terminal atau transit (halte, stasiun, stop) untuk dijangkau dari lokasi-lokasi pusat permukiman dan pusat aktivitas;

2. Seberapa mudah titik-titik tersebut dicapai secara langsung tanpa melalui transfer atau perpindahan moda angkutan;

3. Kombinasi dari nilai aksesibilitas (1) dan (2).

Dalam penelitian ini, dilakukan komparasi dengan membandingkan karakteristik jaringan transportasi publik antara wilayah Sidoarjo-Surabaya dan Gresik-Surabaya.

Contoh penggunaan metode SNAMUTS pada penelitian terdahulu, adalah pada konteks penelitian di Kota Perth, Australia Barat (Scheurer, 2008). Metode SNAMUTS digunakan untuk membandingkan kinerja jaringan transportasi publik di Perth, sebelum dan sesudah penambahan jalur kereta api pada tahun 2008 (Scheurer, 2008). Hasil penelitian tersebut menunjukkan bahwa penambahan jalur kereta api memengaruhi jaringan transportasi publik di Perth, sehinga terjadi; 1) Penurunaan kebutuhan transfer dan hambatan perjalanan, 2) Peningkatan jumlah pusat kegiatan (node) dan daya saing perjalanan menggunakan transportasi publik dibandingkan dengan kendaraan pribadi; dan 3) Perubahan tingkat aksesibilitas pada beberapa wilayah. 


\section{METODE PENELITIAN}

\section{Pendekatan dan Jenis Penelitian}

Pendekatan yang digunakan dalam penelitian ini adalah pendekatan deduktif, yaitu pendekatan yang melakukan pengujian teori berdasarkan hasil pengamatan. Sedangkan jenis penelitian ini merupakan penelitian eksploratif-kualitatif yang bertujuan untuk membentuk dasar penelitian yang lebih konklusif serta dapat membantu dalam penentuan desain penelitian, metodologi pengambilan sampel, serta metodologi pengumpulan data.

\section{Variabel Penelitian}

Variabel yang digunakan dalam penelitian ini terbagi menjadi 7 indikator yaitu karakteristik wilayah, hambatan perjalanan, degree of centrality, closeness centrality, composite accessibility index, tingkat aksesibilitas jaringan transportasi publik, dan faktor pengaruh tingkat aksesibilitas.

Table 1. Indikator dan Variabel Penelitian

\begin{tabular}{|c|c|c|}
\hline No & Indikator & Variabel \\
\hline 1 & Karakteristik Wilayah & $\begin{array}{l}\text { Jumlah Pusat Kegiatan } \\
\text { Jumlah Titik Transit }\end{array}$ \\
\hline 2 & Hambatan Perjalanan & $\begin{array}{l}\text { Waktu Perjalanan } \\
\text { Frekuensi Angkutan } \\
\text { Waktu Pelayanan Angkutan }\end{array}$ \\
\hline 3 & Degree of Centrality & $\begin{array}{l}\text { Jumlah Direct Node } \\
\text { Jumlah Pusat Kegiatan }\end{array}$ \\
\hline 4 & Closeness Centrality & $\begin{array}{l}\text { Hambatan Perjalanan } \\
\text { Jumlah Pusat Kegiatan }\end{array}$ \\
\hline 5 & Composite Accessibility Index & \\
\hline 6 & $\begin{array}{l}\text { Tingkat Aksesibilitas Jaringan } \quad \text { Transportasi } \\
\text { Publik }\end{array}$ & Degree of Centrality \\
\hline 7 & $\begin{array}{l}\text { Faktor Pengaruh } \\
\text { Transportasi Publik }\end{array}$ & $\begin{array}{l}\text { Closeness Centrality } \\
\text { Composite Accessibility Index } \\
\text { Jumlah Trayek Angkutan Umum }\end{array}$ \\
\hline & & $\begin{array}{l}\text { Jumlah Transfer } \\
\text { Jumlah Direct Node } \\
\text { Waktu Perjalanan } \\
\text { Frekuensi Angkutan } \\
\text { Hambatan Perjalanan }\end{array}$ \\
\hline
\end{tabular}

\section{Metode Sampling}

Metode sampling yang digunakan dalam penelitian ini adalah metode clustrer sampling dengan populasi berupa seluruh desa/kelurahan pada 28 kecamatan di kawasan Surabaya Metropolitan Area khususnya wilayah Sidoarjo, Gresik, dan Surabaya. Kabupaten Bangkalan tidak disertakan dalam penelitian karena memiliki arus pergerakan pekerja ulang-alik tidak signifikan sebesar 2,7\% (Statistik, 2017).

Sampel pada penelitian ini berjumlah 47 desa/kelurahan dengan rincian 14 desa/kelurahan di Kabupaten Sidoarjo, 10 desa/kelurahan di Kabupaten Gresik, dan 23 desa/kelurahan di Kota Surabaya. Dalam pemilihan sampel, terdapat dua kriteria yang harus dipenuhi, yaitu: 1) Desa/kelurahan dapat diakses menggunakan minimal satu jenis moda transportasi publik; 2) Memiliki pusat kegiatan berupa kawasan permukiman bagi 
desa di Kabupaten Sidoarjo dan Kabupaten Gresik, kawasan industri atau perdagangan bagi kelurahan di Kota Surabaya.

\section{Teknik Analisis Data}

Penyusunan komparasi tingkat aksesisibilitas jaringan transportasi publik dilakukan melalui tiga sasaran. Sasaran pertama adalah mengidentifikasi karakteristik jaringan transportasi publik di wilayah Sidoarjo-Surabaya dan Gresik-Surabaya dengan analisis statistik deskriptif dan ditampilkan melalui diagram jaringan. Diagram jaringan tersebut disusun dengan memperhatikan frekuensi dan titik perpindahan moda (Neilsen et al., 2005). Input data yang digunakan adalah jumlah pusat kegiatan, jumlah titik transit, waktu perjalanan, frekuensi angkutan, dan waktu pelayanan angkutan. Output yang dihasilkan adalah deskripsi karakteristik jaringan transportasi publik di wilayah SidoarjoSurabaya dan Gresik-Surabaya.

Sasaran kedua adalah mengukur tingkat aksesibilitas jaringan transportasi publik di wilayah Sidoarjo-Surabaya dan Gresik-Surabaya dengan analisis SNAMUTS menggunakan 3 indeks, yaitu degree of centrality, closeness centrality, dan composite accessibility index. Adapun persamaan yang digunakan dalam mengukur tingkat aksesibilitas adalah sebagai berikut (Geurs \& van Wee, 2004).

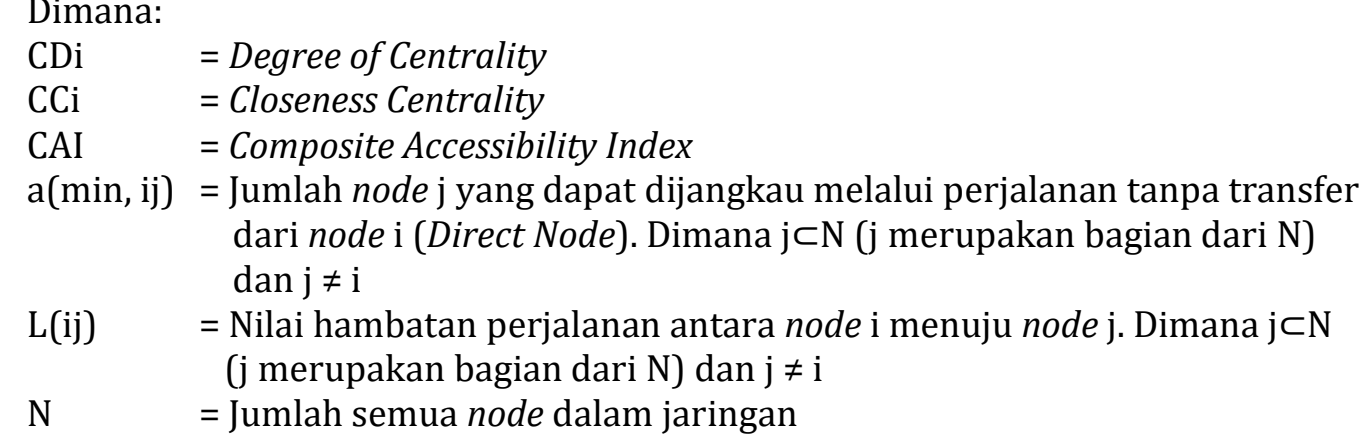

$\mathrm{CCi}=\sum(\mathrm{L}(\mathrm{ij})) /(\mathrm{N}-1)$

$\mathrm{CAI}=2 * \mathrm{CDi}+150 / \mathrm{CCi}$

Output yang dihasilkan adalah peta dan deskripsi karakteristik tingkat aksesibilitas jaringan transportasi publik di wilayah Sidoarjo-Surabaya dan Gresik-Surabaya.

Sasaran tiga adalah mengomparasikan faktor pengaruh tingkat aksesibilitas jaringan transportasi publik antara wilayah Sidoarjo-Surabaya dan Gresik-Surabaya dengan analisis deskriptif statistik dan analisis korelasi. Input data yang digunakan adalah degree of centrality, closeness centrality, composite accessibility index, trayek angkutan umum, jumlah transfer, direct node, waktu perjalanan, frekuensi angkutan, dan hambatan perjalanan. Output yang dihasilkan adalah desksripsi komparasi tingkat aksesibilitas dan faktor pengaruh tingkat aksesibilitas jaringan transportasi publik di wilayah SidoarjoSurabaya dan Gresik-Surabaya.

\section{HASIL DAN PEMBAHASAN}

\section{Karakteristik Jaringan Transportasi Publik di Wilayah Sidoarjo-Surabaya dan Gresik-Surabaya}

Karakteristik jaringan transportasi publik di wilayah Sidoarjo-Surabaya dan GresikSurabaya digambarkan melalui 6 variabel sebagai berikut.

1. Jumlah Pusat Kegiatan (Node) 
Wilayah Sidoarjo-Surabaya memiliki 30 node yang terdiri dari 14 desa di Kabupaten Sidoarjo dan 16 kelurahan di Kota Surabaya. Sedangkan wilayah Gresik-Surabaya memiliki 20 node yang terdiri dari 10 desa di Kabupaten Gresik dan 10 kelurahan di Kota Surabaya. 2. Titik Transit

Wilayah Sidoarjo-Surabaya memiliki 87 titik transit yang terdiri dari 30 halte bus, 4 stasiun kereta api, dan 33 titik transit angkutan kota. Sedangkan wilayah Gresik-Surabaya memiliki 38 titik transit yang terdiri dari 3 stasiun kereta api dan 33 titik transit angkutan kota.

3. Waktu Perjalanan

Pada wilayah Sidoarjo-Surabaya, rata-rata waktu perjalanan antar node adalah 48,7 menit dengan waktu paling lama pada perjalanan dari Desa Sedati Agung menuju Kelurahan Tambak Osowilangun. Sedangkan pada wilayah Gresik-Surabaya, rata-rata waktu perjalanan antar node adalah 56,6 menit dengan waktu paling lama pada perjalanan dari Desa Randuagung menuju Kelurahan Benowo.

4. Frekuensi Angkutan

Rata-rata frekuensi angkutan umum yang melalui wilayah Sidoarjo-Surabaya adalah 3,9 unit per jam. Sedangkan rata-rata frekuensi angkutan umum yang melalui wilayah Gresik-Surabaya adalah 3,7 unit per jam.

5. Hambatan Perjalanan

Pada wilayah Sidoarjo-Surabaya, rata-rata hambatan perjalanan antar node adalah 15,96 dengan hambatan paling besar pada perjalanan dari Desa Sedati Agung menuju Kelurahan Tambak Osowilangun. Sedangkan pada wilayah Gresik-Surabaya, rata-rata hambatan perjalanan antar node adalah 17,9 dengan hambatan paling besar pada perjalanan antara Desa Cerme Lor menuju Kelurahan Perak Timur.

6. Waktu Pelayanan Angkutan

Pada wilayah Sidoarjo-Surabaya dan Gresik-Surabaya, sebagian besar angkutan umum beroperasi sejak pukul 05.00 dan selesai beroperasi pada pukul 18.00 dan 21.00. Angkutan dengan jam operasional paling pagi adalah kereta Surabaya-Porong yang beroperasi sejak pukul 03.25. Sedangkan angkutan dengan jam operasional paling malam adalah bus F Purabaya-Jembatan Merah yang selesai beroperasi pada pukul 23.50.

\section{Tingkat Aksesibilitas Jaringan Transportasi Publik di Wilayah Sidoarjo-Surabaya dan Gresik- Surabaya}

Tingkat aksesibilitas jaringan transportasi publik di wilayah Sidoarjo-Surabaya dan Gresik-Surabaya diukur menggunakan 3 indeks aksesibilitas sebagai berikut.

1. Degree of Centrality

Pada wilayah Sidoarjo-Surabaya, rata-rata nilai indeks degree of centrality dari seluruh node adalah 32\%. Angka tersebut menunjukkan bahwa jaringan transportasi publik yang ada di wilayah Sidoarjo-Surabaya memungkinkan perjalanan secara langsung tanpa perpindahan moda menuju 9 dari 30 node yang ada. Node dengan tingkat aksesibilitas degree of centrality terbaik merupakan node di dekat Terminal Purabaya, seperti Desa Kedungrejo, Medaeng, dan Waru yang dilalui oleh lebih banyak angkutan umum dibandingkan node-node lainnya. Persebaran nilai degree of centrality SidoarjoSurabaya ditampilkan pada Gambar 1.

Pada wilayah Gresik-Surabaya, rata-rata nilai indeks degree of centrality dari seluruh node adalah 35\%. Angka tersebut menunjukkan bahwa jaringan transportasi publik yang ada di wilayah Gresik-Surabaya memungkinkan perjalanan secara langsung tanpa perpindahan moda menuju 7 dari 20 node yang ada. Node dengan tingkat aksesibilitas degree of centrality terburuk merupakan node yang dilalui angkutan umum dengan jumlah terbatas seperti Desa Dahanrejo dan Desa Cerme Lor. Persebaran nilai degree of centrality Gresik-Surabaya ditampilkan pada Gambar 2. 


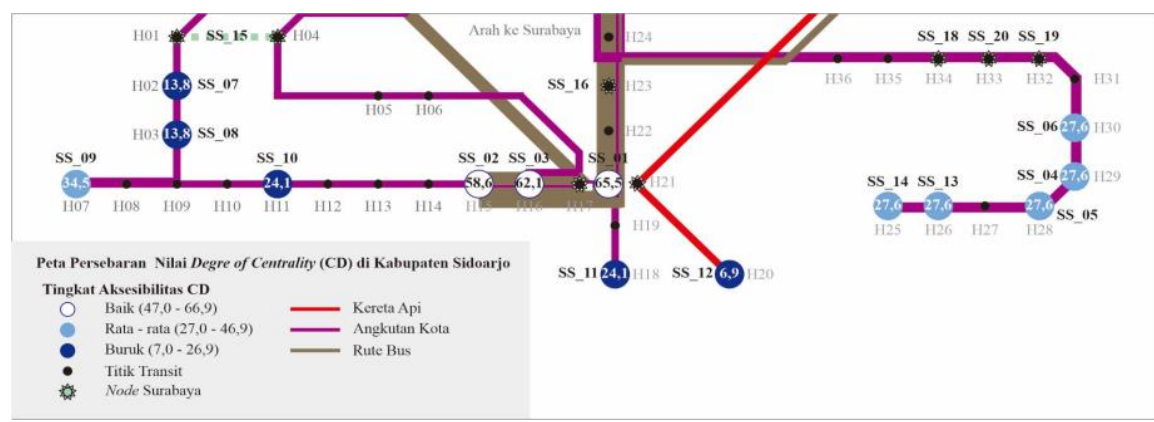

Sumber: hasil analisis, 2020

Gambar 1 Peta Persebaran Nilai Degree of Centrality di Wilayah SidoarjoSurabaya

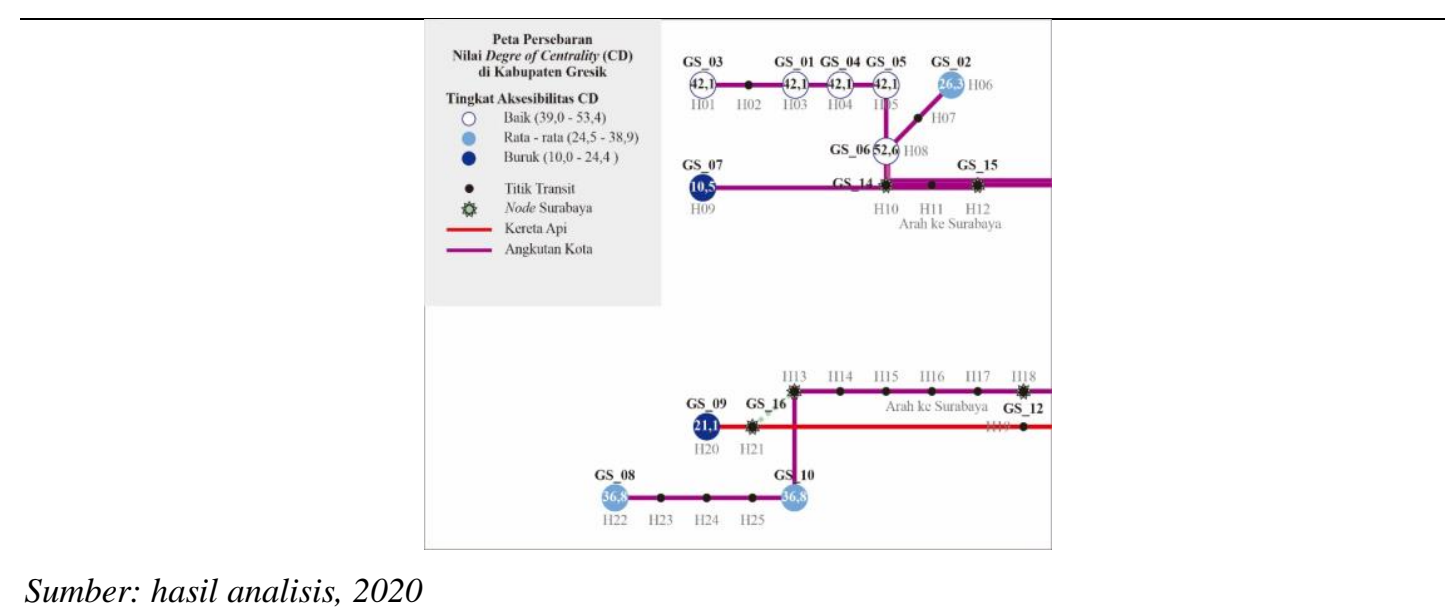

Gambar 2 Peta Persebaran Nilai Degree of Centrality di Wilayah Gresik-Surabaya

\section{Closeness Centrality}

Pada wilayah Sidoarjo-Surabaya, rata-rata nilai indeks closeness centrality dari seluruh node adalah 16. Angka tersebut menunjukkan bahwa perjalanan antar node menggunakan jaringan transportasi publik di wilayah Sidoarjo-Surabaya memiliki ratarata hambatan sebesar 16 poin. Node dengan tingkat aksesibilitas closeness centrality terburuk adalah Desa Sedati Agung yang terletak lebih jauh dari Kota Surabaya dan memiliki frekuensi pelayanan angkutan umum yang kecil. Persebaran nilai closeness centrality Sidoarjo-Surabaya ditampilkan pada Gambar 3.

Pada wilayah Gresik-Surabaya, rata-rata nilai indeks closeness centrality dari seluruh node adalah 19,2. Angka tersebut menunjukkan bahwa perjalanan antar node menggunakan jaringan transportasi publik yang ada di wilayah Gresik-Surabaya memiliki rata-rata hambatan sebesar 19,2 poin. Node dengan tingkat aksesibilitas closeness centrality terburuk adalah Desa Ngembung yang terletak jauh dari Kota Surabaya dan Desa Cerme Lor yang memiliki frekuensi pelayanan angkutan umum sangat kecil. Persebaran nilai closeness centrality Gresik-Surabaya ditampilkan pada Gambar 4. 


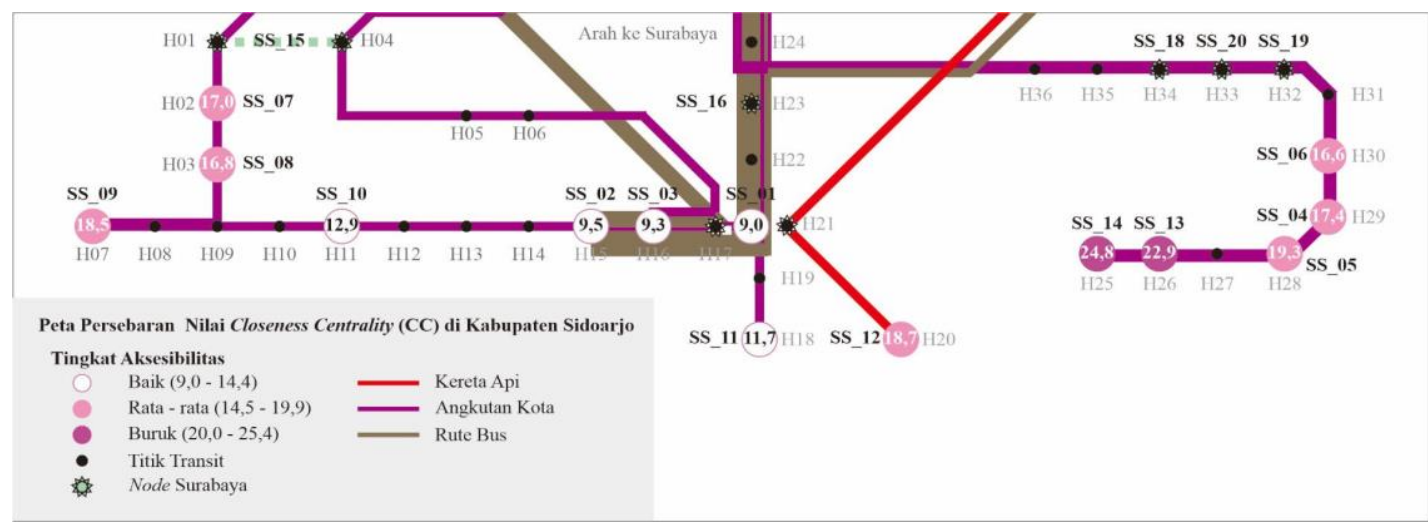

Sumber: hasil analisis, 2020

Gambar 3 Peta Persebaran Nilai Closeness Centrality di Wilayah SidoarjoSurabaya

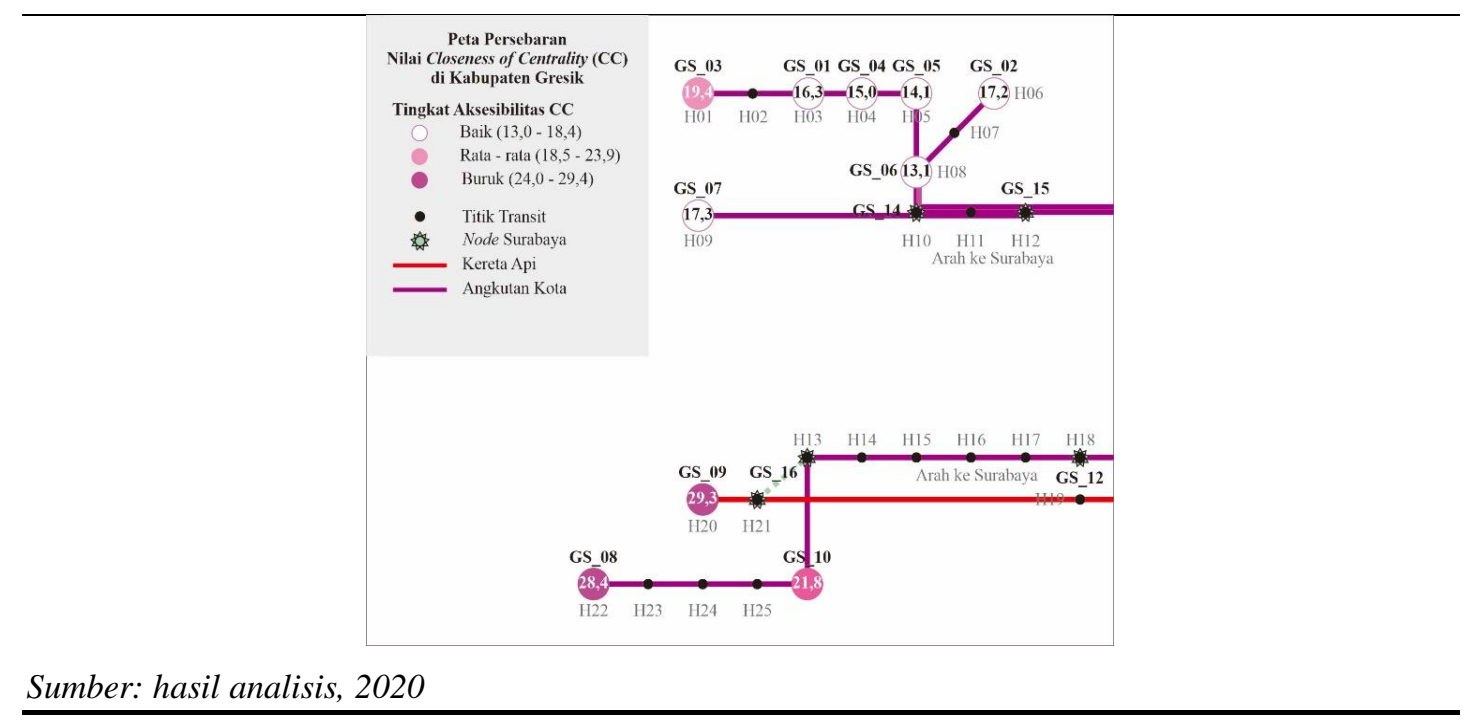

Gambar 4 Peta Persebaran Nilai Closeness Centrality di Wilayah Gresik-Surabaya

\section{Composite Accessibility}

Pada wilayah Sidoarjo-Surabaya, rata-rata nilai indeks composite accessibility index dari seluruh node adalah 11 . Node dengan tingkat aksesibilitas composite accessibility index terbaik merupakan node di dekat Terminal Purabaya seperti Desa Kedungrejo, Medaeng, dan Waru. Sedangkan node dengan tingkat aksesibilitas composite accessibility index terburuk merupakan node-node di Kecamatan Sedati seperti Desa Pabean dan Sedati Agung. Persebaran nilai composite accessibility index Sidoarjo-Surabaya ditampilkan pada Gambar 5.

Pada wilayah Gresik-Surabaya, rata-rata nilai indeks composite accessibility index dari seluruh node adalah 9. Node dengan tingkat aksesibilitas composite accessibility index terbaik merupakan node yang terletak di bagian utara Kabupaten Gresik seperti Desa Segoromadu. Sedangkan node dengan tingkat aksesibilitas composite accessibility index terburuk merupakan node di bagian selatan Kabupaten yang terletak jauh dari Kota Surabaya seperti Desa Cerme Lor. Persebaran nilai composite accessibility index GresikSurabaya ditampilkan pada Gambar 6. 


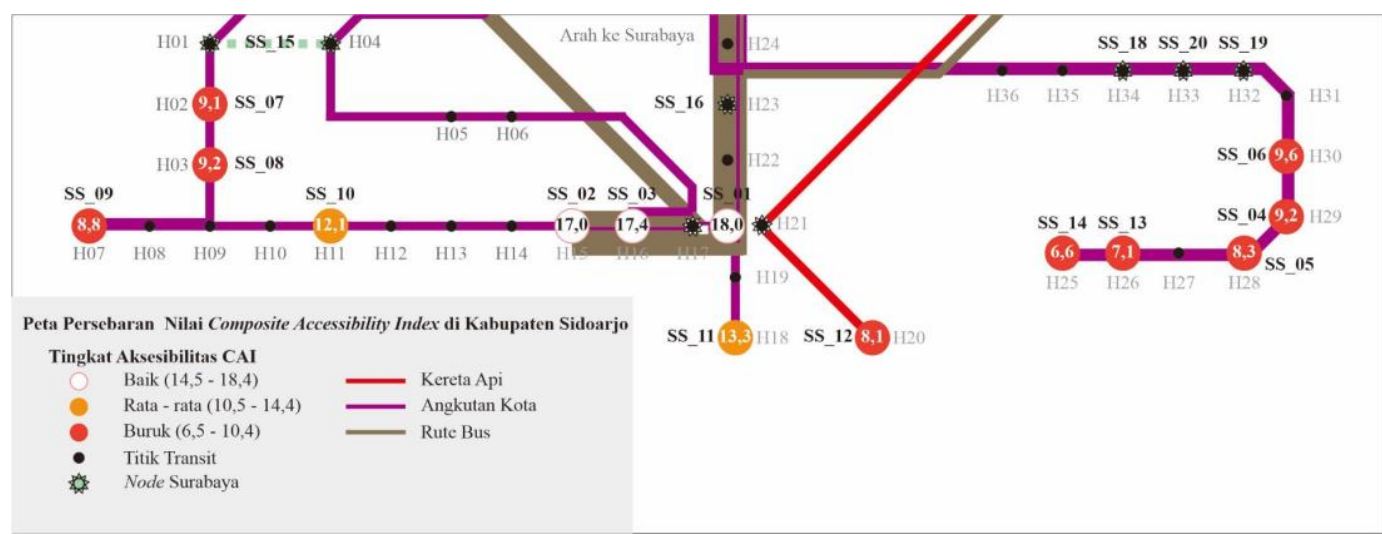

Sumber: hasil analisis, 2020

Gambar 5 Peta Persebaran Nilai Composite Accessibility Index di Wilayah Sidoarjo-Surabaya

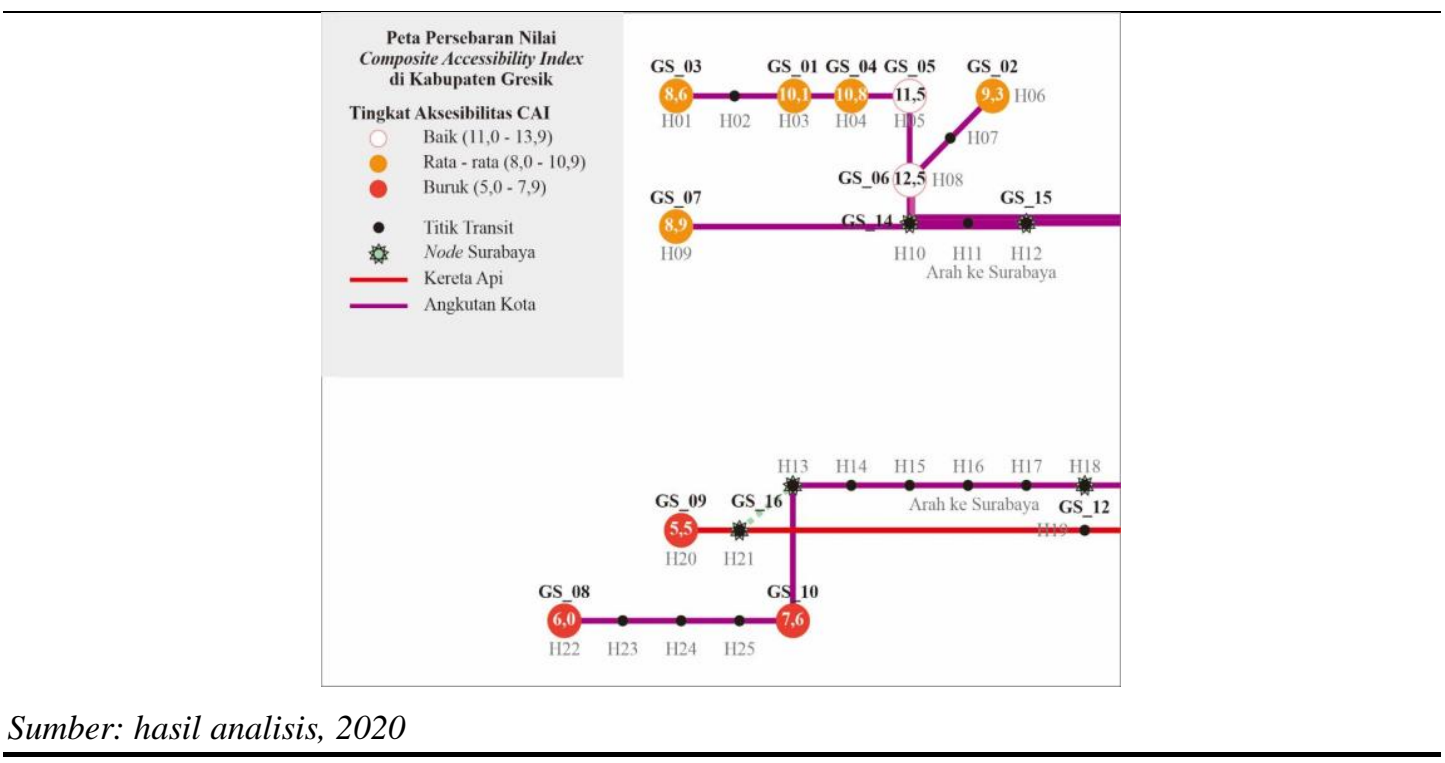

\section{Gambar 6 Peta Persebaran Nilai Composite Accessibility Index di Wilayah Gresik- Surabaya}

\section{Komparasi Faktor Pengaruh Tingkat Aksesibilitas Jaringan Transportasi Publik Antara Wilayah Sidoarjo-Surabaya Dan Gresik-Surabaya}

Komparasi faktor yang mempengaruhi tingkat aksesibilitas jaringan transportasi publik antara wilayah Sidoarjo-Surabaya dan Gresik-Surabaya dilakukan dengan membandingkan tingkat aksesibilitas dan faktor pengaruh aksesibilitas dari ketiga indeks aksesibilitas. Berikut ditampilkan hasil analisis tersebut.

\section{Degree of Centrality}

Pada indeks degree of centrality, wilayah Gresik-Surabaya memiliki rata-rata yang lebih tinggi 3\% daripada wilayah Sidoarjo-Surabaya. Namun, dari segi jangkauan nilai indeks, wilayah Sidoarjo-Surabaya memiliki tingkat aksesibilitas yang lebih baik dengan nilai maksimal 66\% yang lebih besar dibandingkan nilai maksimal wilayah GresikSurabaya sebesar $52 \%$. 
Indeks degree of centrality dipengaruhi oleh 3 variabel yaitu trayek angkutan umum, jumlah transfer, dan direct node (Geurs \& van Wee, 2004). Berikut ditampilkan tabel perbandingan ketiga variabel pada wilayah Sidoarjo-Surabaya dan Gresik-Surabaya.

Tabel 2. Komparasi Faktor Pengaruh Degree of Centrality

\begin{tabular}{clcc}
\hline \multirow{2}{*}{ No } & Faktor Pengaruh & Sidoarjo-Surabaya & Gresik-Surabaya \\
\hline 1 & Trayek Angkutan Umum & 3,7 & 1,1 \\
2 & Jumlah Transfer & 0,6 & 1,0 \\
3 & Direct Node & 9,1 & 6,7 \\
\hline
\end{tabular}

Sumber: hasil analisis, 2020

Pada ketiga faktor, wilayah Sidoarjo-Surabaya memiliki nilai faktor yang lebih baik daripada wilayah Gresik-Surabaya. Rata-rata jumlah trayek angkutan umum yang lebih banyak di wilayah Sidoarjo-Surabaya memungkinkan terjadinya perjalanan tanpa transfer ke node yang lebih banyak daripada wilayah Gresik-Surabaya. Jumlah trayek yang lebih banyak juga memungkinkan wilayah Sidoarjo-Surabaya mengurangi jumlah transfer dalam melakukan perjalanan antar node.

Selanjutnya dilakukan analisis korelasi untuk mengetahui signifikansi hubungan antara faktor pengaruh dan indeks aksesibilitas degree of centrality.

Tabel 3. Hubungan Faktor Pengaruh dengan Degree of Centrality

\begin{tabular}{clcc}
\hline No & Faktor Pengaruh & Signifikansi & Koefisien Korelasi \\
\hline 1 & Trayek Angkutan Umum & 0,000 & 0,725 \\
2 & Jumlah Transfer & 0,005 & 0,554 \\
3 & Direct Node & 0,000 & 0,909 \\
& & \\
\hline
\end{tabular}

Berdasarkan analisis tersebut diketahui bahwa ketiga variabel memiliki nilai signifikansi yang lebih kecil daripada 0,05 sehingga ketiga variabel merupakan faktor yang memiliki hubungan dengan indeks degree of centrality. Dari ketiga variabel, direct node merupakan variabel dengan hubungan paling kuat dengan indeks degree of centrality.

2. Closeness Centrality

Pada indeks closeness centrality, wilayah Sidoarjo-Surabaya memiliki rata-rata yang lebih rendah 3,2 poin daripada wilayah Gresik-Surabaya. Hal tersebut menunjukkan bahwa hambatan pada perjalanan menggunakan jaringan transportasi publik di wilayah Sidoarjo-Surabaya lebih rendah daripada wilayah Gresik-Surabaya.

Indeks closeness centrality dipengaruhi oleh 3 variabel yaitu waktu perjalanan, frekuensi angkutan umum, dan hambatan perjalanan (Geurs \& van Wee, 2004). Berikut ditampilkan tabel perbandingan ketiga variabel pada wilayah Sidoarjo-Surabaya dan Gresik-Surabaya.

Tabel 4. Komparasi Faktor Pengaruh Closeness Centrality

\begin{tabular}{clcc}
\hline \multirow{2}{*}{ No } & \multicolumn{1}{c}{ Faktor Pengaruh } & Sidoarjo-Surabaya & Gresik-Surabaya \\
\hline 1 & Waktu Perjalanan & 48,7 & 56,6 \\
2 & Frekuensi Angkutan Umum & 3,9 & 3,7 \\
3 & Hambatan Perjalanan & 16,0 & 17,9 \\
\hline
\end{tabular}

Sumber: hasil analisis, 2020 
Pada ketiga faktor, wilayah Sidoarjo-Surabaya memiliki nilai faktor yang lebih baik daripada wilayah Gresik-Surabaya. Rata-rata waktu perjalanan yang lebih singkat serta frekuensi angkutan umum yang lebih besar mengakibatkan wilayah Sidoarjo-Surabaya memiliki hambatan perjalanan yang lebih kecil daripada wilayah Gresik-Surabaya.

Selanjutnya dilakukan analisis korelasi untuk mengetahui signifikansi hubungan antara faktor pengaruh dan indeks aksesibilitas closeness centrality.

Tabel 5. Hubungan Faktor Pengaruh dengan Closeness Centrality

\begin{tabular}{clcc}
\hline No & \multicolumn{1}{c}{ Faktor Pengaruh } & Signifikansi & Koefisien Korelasi \\
\hline 1 & Waktu Perjalanan & 0,000 & 0,827 \\
2 & Frekuensi Angkutan Umum & 0,000 & 0,683 \\
3 & Hambatan Perjalanan & 0,000 & 1,000 \\
& mber: hasil analisis, 2020 & & \\
\hline
\end{tabular}

Berdasarkan analisis tersebut, diketahui bahwa ketiga variabel memiliki nilai signifikansi yang lebih kecil daripada 0,05 sehingga ketiga variabel merupakan faktor yang memiliki hubungan dengan indeks closeness centrality. Dari ketiga variabel, hambatan perjalanan merupakan variabel dengan hubungan paling kuat dengan indeks closeness centrality.

\section{Composite Accessibility Index}

Pada composite accessibility index, wilayah Sidoarjo-Surabaya memiliki rata-rata yang lebih tinggi 1,9 poin daripada wilayah Gresik-Surabaya. Hal tersebut menunjukkan bahwa tingkat aksesibilitas jaringan transportasi publik di wilayah Sidoarjo-Surabaya lebih baik daripada wilayah Gresik-Surabaya. Pada kedua wilayah, node dengan tingkat aksesibilitas yang baik, seperti Desa Segoromadu dan Desa Kedungrejo, merupakan kawasan pusat permukiman yang berada di dekat terminal dan lebih dekat dengan Kota Surabaya dibandingkan node-node lain.

Composite accessibility index dipengaruhi oleh 6 variabel yaitu trayek angkutan umum, jumlah transfer, direct node, waktu perjalanan, frekuensi angkutan umum, dan hambatan perjalanan (Geurs \& van Wee, 2004). Berikut ditampilkan tabel perbandingan keenam variabel pada wilayah Sidoarjo-Surabaya dan Gresik-Surabaya.

Tabel 6. Komparasi Faktor Pengaruh Composite Accessibility Index

\begin{tabular}{clcc}
\hline No & \multicolumn{1}{c}{ Faktor Pengaruh } & Sidoarjo-Surabaya & Gresik-Surabaya \\
\hline 1 & Trayek Angkutan Umum & 3,7 & 1,1 \\
2 & Jumlah Transfer & 0,6 & 1,0 \\
3 & Direct Node & 9,1 & 6,7 \\
4 & Waktu Perjalanan & 48,7 & 56,6 \\
5 & Frekuensi Angkutan Umum & 3,9 & 3,7 \\
6 & Hambatan Perjalanan & 16,0 & 17,9 \\
\hline
\end{tabular}

Sumber: hasil analisis, 2020

Perbandingan keenam faktor telah dijelaskan pada bagian sebelumnya. Secara umum wilayah Sidoarjo-Surabaya memiliki nilai faktor yang lebih baik dibandingkan wilayah Gresik-Surabaya. Selanjutnya dilakukan analisis korelasi untuk mengetahui signifikansi hubungan antara faktor pengaruh dan composite accessibility index. 
Tabel 7. Hubungan Faktor Pengaruh dengan Composite Accessibility Index

\begin{tabular}{clcc}
\hline No & \multicolumn{1}{c}{ Faktor Pengaruh } & Signifikansi & Koefisien Korelasi \\
\hline 1 & Trayek Angkutan Umum & 0,000 & 0,811 \\
2 & Jumlah Transfer & 0,000 & 0,686 \\
3 & Direct Node & 0,000 & 0,794 \\
4 & Waktu Perjalanan & 0,000 & 0,833 \\
5 & Frekuensi Angkutan Umum & 0,000 & 0,799 \\
6 & Hambatan Perjalanan & 0,000 & 0,914 \\
\hline
\end{tabular}

Sumber: hasil analisis, 2020

Berdasarkan analisis tersebut, diketahui bahwa keenam variabel memiliki nilai signifikansi yang lebih kecil daripada 0,05 sehingga keenam variabel merupakan faktor yang memiliki hubungan dengan composite accessibility index. Dari keenam variabel, hambatan perjalanan merupakan variabel dengan hubungan paling kuat dengan composite accessibility index.

Setelah mengetahui faktor pengaruh aksesibilitas, dilakukan analisis regresi linear berganda untuk mengetahui besar intervensi yang dapat dilakukan terhadap faktor-faktor di wilayah Sidoarjo-Surabaya. Berdasarkan analisis tersebut, diperoleh model persamaan regresi di wilayah Sidoarjo-Surabaya dan Gresik-Surabaya sebagai berikut.

$$
\begin{array}{rl}
\text { CAISDA }_{\text {S }}=-29.1599+0.54392 \mathrm{DN}+5.11489 \mathrm{FA}-0.388699 \mathrm{HP}+ \\
& 31.8853 \mathrm{JT}+0.016367 \mathrm{TA}-0.000502467 \mathrm{WP} \\
\text { CAI }_{\mathrm{GRK}} & 12.2005+1.15569 \mathrm{FA}+0.970385 \mathrm{TA}-0.142364 \mathrm{WP}
\end{array}
$$

\begin{tabular}{|c|c|}
\hline Dimana: & \\
\hline CAISDA $_{\text {SD }}$ & = Composite Accessibility Index Sidoarjo-Surabaya \\
\hline $\mathrm{CAI}_{\mathrm{GRK}}$ & = Composite Accessibility Index Gresik-Surabaya \\
\hline $\mathrm{DN}$ & $=$ Jumlah Direct Node \\
\hline FA & $=$ Frekuensi Angkutan \\
\hline $\mathrm{HP}$ & = Hambatan Perjalanan \\
\hline $\mathrm{JT}$ & $=$ Jumlah Transfer \\
\hline TA & = Trayek Angkutan Umum \\
\hline WP & = Waktu Perjalanan \\
\hline
\end{tabular}

Setelah persamaan regresi diperoleh, dilakukan penghitungan besar intervensi yang dapat dilakukan pada node dengan tingkat aksesibilitas rendah. Intervensi tersebut dilakukan pada variabel hambatan perjalanan, jumlah trayek, waktu perjalanan, dan frekuensi angkutan yang memiliki pengaruh paling besar terhadap tingkat aksesibilitas.

Pada Desa Sedati Agung dan Pabean yang merupakan kawasan permukiman di Kecamatan Sedati serta Desa Tropodo yang merupakan kawasan permukiman di Kecamatan Waru, Kabupaten Sidoarjo, intervensi yang dapat dilakukan adalah: (1) Peningkatan 1 poin frekuensi; (2) Pengurangan waktu perjalanan sebesar 8 menit melalui pembatasan wkatu transit. Melalui intervensi tersebut, tingkat aksesibilitas kedua node meningkat menjadi 15,3 poin yang lebih besar dari rata-rata wilayah Sidoarjo -Surabaya yaitu 10.

Pada Desa Gedangan yang merupakan kawasan permukiman di Kecamatan Gedangan, Kabupaten Sidoarjo, intervensi yang dapat dilakukan adalah penambahan trayek angkutan karena node ini hanya dilalui jaringan kereta api dengan jumlah perjalanan yang sangat terbatas. Penambahan 1 trayek angkutan umum dapat meningkatkan aksesibilitas sebesar 5 poin menjadi 13,0. 
Pada Desa Cerme Lor dan Ngembung yang merupakan kawasan permukiman di Kecamatan Cerme, Kabupaten Gresik, intervensi yang dapat dilakukan adalah penambahan trayek dan frekuensi angkutan umum serta pengurangan waktu perjalanan. Penambahan jumlah trayek angkutan diperlukan karena hanya terdapat 1 trayek angkutan eksisting berupa kereta api di Desa Cerme Lor, serta angkutan kota di Desa Ngembung. Penambahan trayek angkutan akan memperluas opsi moda transportasi penduduk di Kecamatan Cerme. Sedangkan peningkatan frekuensi sebesar 1 poin dan pengurangan waktu perjalanan sebesar 10 menit dapat mengurangi hambatan perjalanan sehingga terjadi peningkatan aksesibilitas sebesar 3,9 poin pada Desa Ngembung dan 6,1 poin pada Desa Cerme Lor.

Pada Desa Kepatihan yang merupakan kawasan permukiman di Kecamatan Menganti, Kabupaten Gresik, intervensi dapat dilakukan melalui penambahan 1 trayek angkutan umum berupa angkutan kota untuk menambah opsi moda transportasi bagi penduduk Kecamatan Menganti. Penambahan trayek tersebut meningkatkan aksesibilitas di Desa Kepatihan sebesar 2,9 poin menjadi 11,5.

Hasil penelitian ini menunjukkan bahwa tingkat aksesibilitas jaringan transportasi publik bagi pekerja ulang-alik di kawasan Surabaya Metropolitan Area dipengaruhi oleh variabel jumlah direct node, frekuensi angkutan, hambatan perjalanan, jumlah transfer, trayek angkutan umum, dan waktu perjalanan. Oleh karena itu, perlu dilakukan intervensi terhadap variabel-variabel tersebut untuk memperbaiki aksesibilitas. Intervensi terhadap variabel-variabel tersebut sejalan dengan preferensi pekerja sebagai pelaku perjalanan yang dipengaruhi oleh kemudahan mencapai tujuan (Natasha \& Handayeni, 2019) dan waktu perjalanan menggunakan moda transportasi publik (Louisa, 2016).

\section{KESIMPULAN}

Pada kawasan Surabaya Metropolitan Area, tingkat aksesibilitas jaringan transportasi publik bagi pekerja ulang-alik dipengaruhi oleh variabel jumlah direct node, frekuensi angkutan, hambatan perjalanan, jumlah transfer, trayek angkutan umum, dan waktu perjalanan. Dari keenam variabel tersebut, tiga variabel yang paling berpengaruh dan dapat diintervensi untuk meningkatkan aksesibilitas sekaligus potensi peralihan moda adalah variabel jumlah trayek angkutan umum, waktu perjalanan, dan frekuensi angkutan.

Intervensi ketiga variabel tersebut dilakukan secara berbeda pada wilayah SidoarjoSurabaya dan Gresik-Surabaya. Pada wilayah Sidoarjo-Surabaya, intervensi berupa penambahan 1 trayek angkutan umum pada Kecamatan Gedangan serta peningkatan frekuensi angkutan umum menjadi 4 unit per jam pada Kecamatan Waru dan Sedati. Sedangkan pada wilayah Gresik-Surabaya, intervensi berupa penambahan 1 trayek angkutan umum di Kecamatan Menganti dan peningkatan frekuensi angkutan umum menjadi 4 unit per jam pada Kecamatan Cerme.

Berdasarkan hasil penelitian ini, terdapat beberapa rekomendasi sebagai berikut; (1) Perlunya penelitian lanjutan menggunakan indeks aksesibilitas lainnya seperti contour catchment, betweeness centrality, dan congested speed ratio; (2) Perlunya kerjasama antara pemerintah Kota Surabaya, Kabupaten Sidoarjo, dan Kabupaten Gresik untuk mengembangkan jaringan transportasi publik yang lebih terintegrasi.

\section{DAFTAR PUSTAKA}

Curtis, C., \& Scheurer, J. (2010). Planning for sustainable accessibility: Developing tools to aid discussion and decision-making. Progress in Planning, 74(2), 53-106. https://doi.org/10.1016/j.progress.2010.05.001

Geurs, K. T., \& van Wee, B. (2004). Accessibility evaluation of land-use and transport strategies: Review and research directions. Journal of Transport Geography, 12(2), 127-140. https://doi.org/10.1016/j.jtrangeo.2003.10.005

Grengs, J. (2010). Job accessibility and the modal mismatch in Detroit. Journal of Transport Geography, 18(1), 
42-54.

Jawa Timur, G. PERATURAN DAERAH PROVINSI JAWA TIMUR NOMOR 5 TAHUN 2012 Tentang Rencana Tata Ruang Wilayah Provinsi Tahun 2011-2031, 66 § (2012).

Jiang, Y. (2017). Urban Accessibility Measurement and Visualization-A Big Data Approach.

Litman, T. (2017). Evaluating accessibility for transport planning: measuring people's ability to reach desired goods and activities. Victoria Transport Policy Institute.

Louisa, V. (2016). Potensi Pengalihan Moda Sepeda Motor Ke Angkutan Kota Bagi Pekerja Ulang-Alik GresikSurabaya (Studi Kasus: Kecamatan Menganti). Institut Teknologi Sepuluh Nopember.

Natasha, S., \& Handayeni, K. D. M. E. (2019). Model Probabilitas Penggunaan Moda Kereta Komuter Bagi Pekerja Ulang-Alik Sidoarjo-Surabaya di Kecamatan Waru. Jurnal Teknik ITS, 7(2), E93-E98.

Neilsen, G., Nelson, J. D., Mulley, C., Tegner, G., Lind, G., \& Lange, T. (2005). HiTrans Best Practice Guide 2: Public Transport-Planning the Networks. HiTrans, Stavanger.

Páez, A., Scott, D. M., \& Morency, C. (2012). Measuring accessibility: positive and normative implementations of various accessibility indicators. Journal of Transport Geography, 25, 141-153.

Scheurer, J. (2008). Discursive Modelling for Land Use-Transport Integration: An Explorative Case Study from Perth, Western Australia. In ACSP-AESOP Joint Congress, Chicago (IL), USA (pp. 6-11).

Setyodhono, S. (2017). Faktor yang mempengaruhi pekerja komuter di jabodetabek menggunakan moda transportasi utama. Warta Penelitian Perhubungan, 29(1), 21-32.

Statistik, B. P. (2017). Statistik Komuter Gerbangkertosusila. Jakarta.

Umilia, E. (2013). Faktor-faktor yang mempengaruhi masyarakat dalam memilih lokasi hunian peri urban Surabaya di Sidoarjo. Jurnal Teknik ITS, 2(2), C143-C148.

Winarno, B., \& Risdianto, O. (2018). PARAMETER PENENTU PENGGUNAAN TRANSPORTASI UMUM DI PERKOTAAN PATI. Jurnal Tataloka, 20(1).

Yagi, S., Aida, Y., Nagayama, K., \& Kudo, T. (2009). Formulation of Transportation Action Plan for the Surabaya Metropolitan Area. Proceedings of the Eastern Asia Society for Transportation Studies, 2009, 25. https://doi.org/10.11175/eastpro.2009.0.25.0 